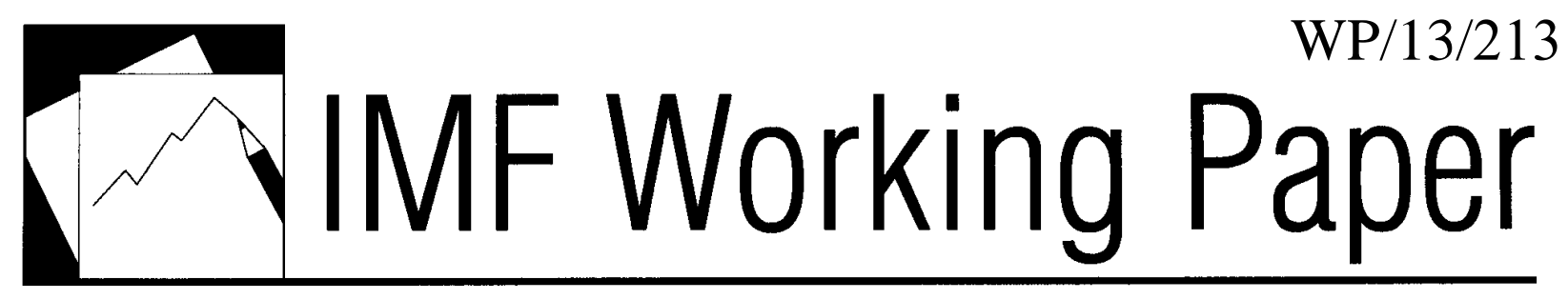

\title{
Outlook for Interest Rates and Japanese Banks' Risk Exposures under Abenomics
}

Serkan Arslanalp and W. Raphael Lam 


\title{
IMF Working Paper
}

Asia and Pacific Department and Monetary and Capital Markets Department

\section{Outlook for Interest Rates and Japanese Banks’ Risk Exposures under Abenomics Prepared by Serkan Arslanalp and W. Raphael Lam ${ }^{1}$}

Authorized for distribution by Stephan Danninger and Luc Everaert

October 2013

\section{This Working Paper should not be reported as representing the views of the IMF.} The views expressed in this Working Paper are those of the author(s) and do not necessarily represent those of the IMF or IMF policy. Working Papers describe research in progress by the author(s) and are published to elicit comments and to further debate.

\begin{abstract}
This paper examines how Japan's long-term interest rates and Japanese banks' interest rate risk exposures may evolve under Abenomics. Results from a panel regression analysis for major advanced economies shows that long-term government bond yields in Japan are determined to a large extent by growth and inflation outlook, fiscal conditions, demography, and the investor base of government securities. A further deterioration of fiscal conditions would push up long-term rates by about 2 percentage points over the medium term, but the rise is partly offset by higher demand for safe assets amid population aging and increased purchases by the Bank of Japan. At the same time, illustrative scenarios suggest the interest rate risk exposure of Japanese banks could decline substantially over the next two years.

However, if structural and fiscal reforms are incomplete, both long-tem yields and interest-risk exposures of Japanese banks could increase over the medium term.
\end{abstract}

JEL Classification Numbers: E4, E6, G1

Keywords: Abenomics, interest rate risks; sovereign yields, unconventional monetary policy, Japanese government bonds (JGB).

Author's E-Mail Address: sarslanalp@imf.org; wlam@imf.org

\footnotetext{
${ }^{1}$ We would like to thank the seminar participants at the Bank of Japan, Federal Reserve Board, and International Monetary Fund. The authors are grateful for constructive comments from Hibiki Ichiue, Toshi Kurosawa, Alasdair Scott, Noburo Sugimoto, Hideyuki Tanimoto, Kiichi Tokuoka, and Kazuaki Washimi.
} 


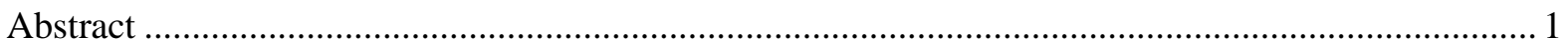

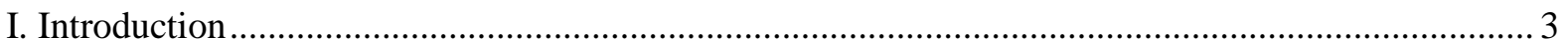

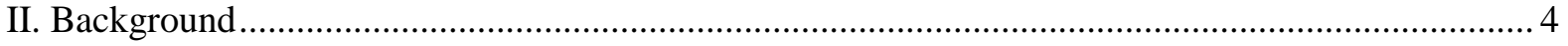

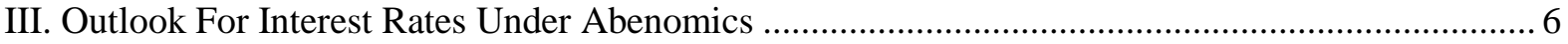

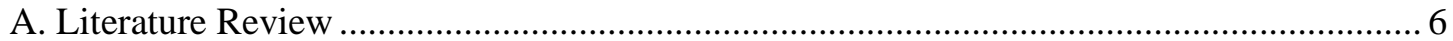

B. A Panel Analysis on the Determinants of Long-Term Interest Rates................................. 9

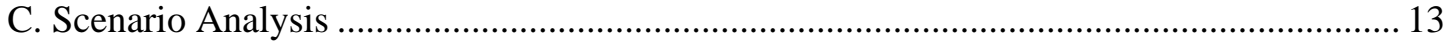

IV. Outlook For Interest Rate Risk Exposures of Japanese Banks under Abenomics ........................ 16

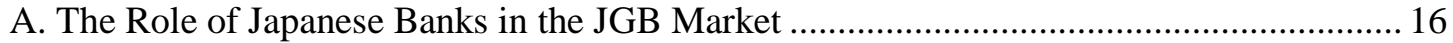

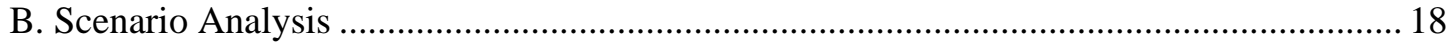

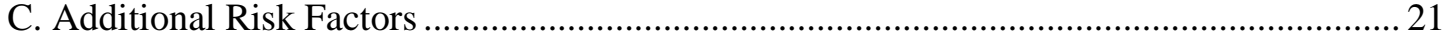

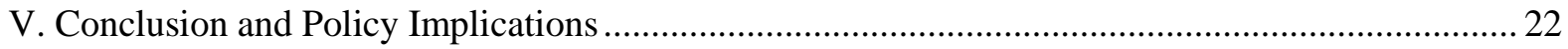

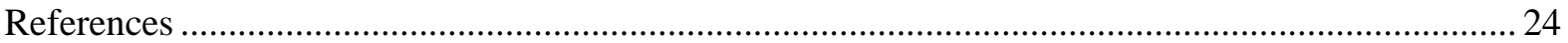

Tables

1. Description of Analytical Scenarios on the Policy Package under Abenomics....................6

2. Descriptive Statistics for Selected Countries in the Panel .................................................10

3. Estimation of Determinants of Long-Term Interest Rates...........................................12

4. Projected Net Purchases of JGBs, 2013-17 ...............................................................199

Figures

1. JGB Market under Abenomics......................................................................................

2. Public Debt and Factors Contributing to Low Interest Rates ......................................... 7

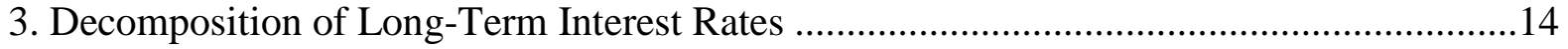

4. Outlook for the Household's Capacity in Financing JGBs...........................................15

5. Demand and Supply Balance in the JGB Market .................................................... 17

6. Domestic Bond Holdings of Major and Regional Banks.................................................19

7. Japanese Banks' Sensitivity to a 100-Basis-Point Interest Rate Shock ............................21 


\section{INTRODUCTION}

Despite the rise in public debts and widening deficits, Japanese government bond (JGB) yields have remained low and stable. Long-term JGB yields have declined steadily from 7 percent in the 1990s to below 1 percent now, while net public debt has risen from 20 percent of GDP to 134 percent of GDP in 2012. With public deficits expected to stay above 5 percent up until 2015, net public debt will likely be close to 150 percent by 2020, the highest among major advanced economies. Low and stable yields in JGBs are often attributed to Japan's sizeable pool of household savings, steady inflows from corporate surpluses, a stable domestic investor base, higher risk aversion as the population ages, and until recently, safe-haven flows from heightened global risks.

At the same time, large JGB holdings of Japanese banks imply that even a modest rise in interest rates can have important implication for financial stability. The large issuance of JGBs over the last two decades has been financed mostly through the domestic financial sector, with banks' JGB holdings currently around 20 percent of total assets and representing an important exposure to interest rate risk. If interest rates were to rise sharply, losses from such exposures could reduce capital ratios across a range of financial institutions. For instance, a 100 basis point parallel rise in domestic bond yields could lead to mark-to-market losses of 13 percent of Tier I capital for major banks and 21 percent for regional banks based on latest available data (Bank of Japan 2013).

This paper studies how Japan's new macroeconomic policies may affect bond yields and financial stability. Japan embarked in 2013 on a new policy strategy - the "three arrows of Abenomics' - in an effort to lift growth and exit deflation. ${ }^{2}$ Financial markets exhibited high volatility in the immediate aftermath of the monetary easing framework adopted by the Bank of Japan (BoJ), but have settled down in the following months. The longer-term impact of the policy package on financial markets is, however, uncertain and depends on whether all the measures are fully implemented. Given the fundamental change in Japan's policy framework this paper studies three key questions:

- Can the policy package of Abenomics continue to hold down JGB yields in the face of rising public debt?

- How will the policy package change the outlook on public debt?

- Will the policy package, including BoJ's asset purchases, help reduce banks' JGB holdings and interest rate risk exposure over the medium-term?

Based on empirical and scenario analyses, the paper finds supporting evidence for these questions, but the results are conditional on all three arrows being implemented. First, the paper examines the key determinants of long-term sovereign yields using a panel of advanced economies and identifies the key contributing factors to project Japan's long-term yields. It finds

\footnotetext{
${ }^{2}$ The government's three-pronged approach to revitalize Japan—known as Abenomics-includes flexible fiscal policy, aggressive monetary easing, and structural reforms. In that context, the Bank of Japan has introduced a new quantitative and qualitative monetary easing (QQME) framework by doubling the purchase size of JGBs and extending the average maturity of JGB holdings to meet the 2 percent inflation target within two years.
} 
that deteriorating fiscal conditions would push up long-term rates, and the effect is only partly offset by demographic factor, stable investor base due to home bias, and an increasing role of the BoJ's purchases. In particular, the paper finds that, looking forward, sovereign yields could rise, as in Hoshi and Ito (2012), unless a full policy package - comprising monetary easing and credible medium-term fiscal and structural reforms - help contain the rise. Second, under incomplete policies, gross government debt could exceed household financial assets - an indicator of domestic market's capacity in financing JGBs - over a decade, requiring higher reliance on foreign investors, and possibly also raising sovereign yields. Third, the paper examines the role of Japanese banks in the JGB markets and how BoJ's new monetary framework may affect their balance sheets. Based on this analysis, the paper illustrates that Japanese banks' interest rate risk exposures could decline substantially over the next two years as the BoJ becomes a large buyer of JGBs, but may rise again to current levels if structural and fiscal reforms disappoint over the medium-term.

The paper extends previous studies in a few dimensions. First, it is the first analysis, to the authors' knowledge, to account for Japan's recent policy changes on the outlook for the JGB market and banks' interest rate risk exposures. Besides providing quantitative empirical results of determinants of long-term yields and interest rate risk exposures in banks' balance sheet, the paper also illustrates the possible trajectory of yields and the market's capacity to finance the JGBs over the long term. Second, the paper takes advantage of the newly-compiled dataset on the investor base of sovereign debts across advanced economies (Arslanalp and Tsuda 2012). Sovereign yields and banks' interest exposures depend not only on the size of public debt, but also on who holds the debt. This is particularly relevant for Japan, as the BoJ will become an even larger player in the JGB market.

The paper is organized as follows. Section II provides some background on the government's new policy package and illustrates potential scenarios based on its implementation. Section III examines the key determinants of long-term sovereign yields using a panel of major advanced economies. Empirical results are used to illustrate the development of long-term yields and the financing outlook for the JGB market over the long term under these scenarios. Section IV analyzes how Japanese banks' interest rate risk exposures may change under these scenarios. Section V concludes with some policy implications.

\section{BACKGROUND}

The Japanese government has announced a new policy approach to exit deflation and lift potential growth. The new strategy - also known as the "three arrows of Abenomics" —includes a package of policies comprises aggressive monetary easing, flexible fiscal policy, and structural reforms. As a first step the government introduced a fiscal stimulus program and the BoJ has introduced a new quantitative and qualitative monetary easing (QQME) framework by doubling the purchases of JGB and extending the average maturity of JGB holdings to meet the 2 percent inflation target within two years (Figure 1).

Financial markets exhibited unusual volatility in the immediate aftermath of the QQME announcement, with JGB volatility about four times higher than the average since the last spike in 2003 (Figure 1). This volatility likely reflected uncertainty about the net effect from two opposing effects, namely the BoJ purchases to keep long-term interest rates low and its intention 
to raise inflation expectations that tend to raise nominal bond yields. The uncertainty on future JGB yields is of particular importance for Japanese financial institutions, which hold nearly three-quarters of outstanding JGBs as of end-2012.

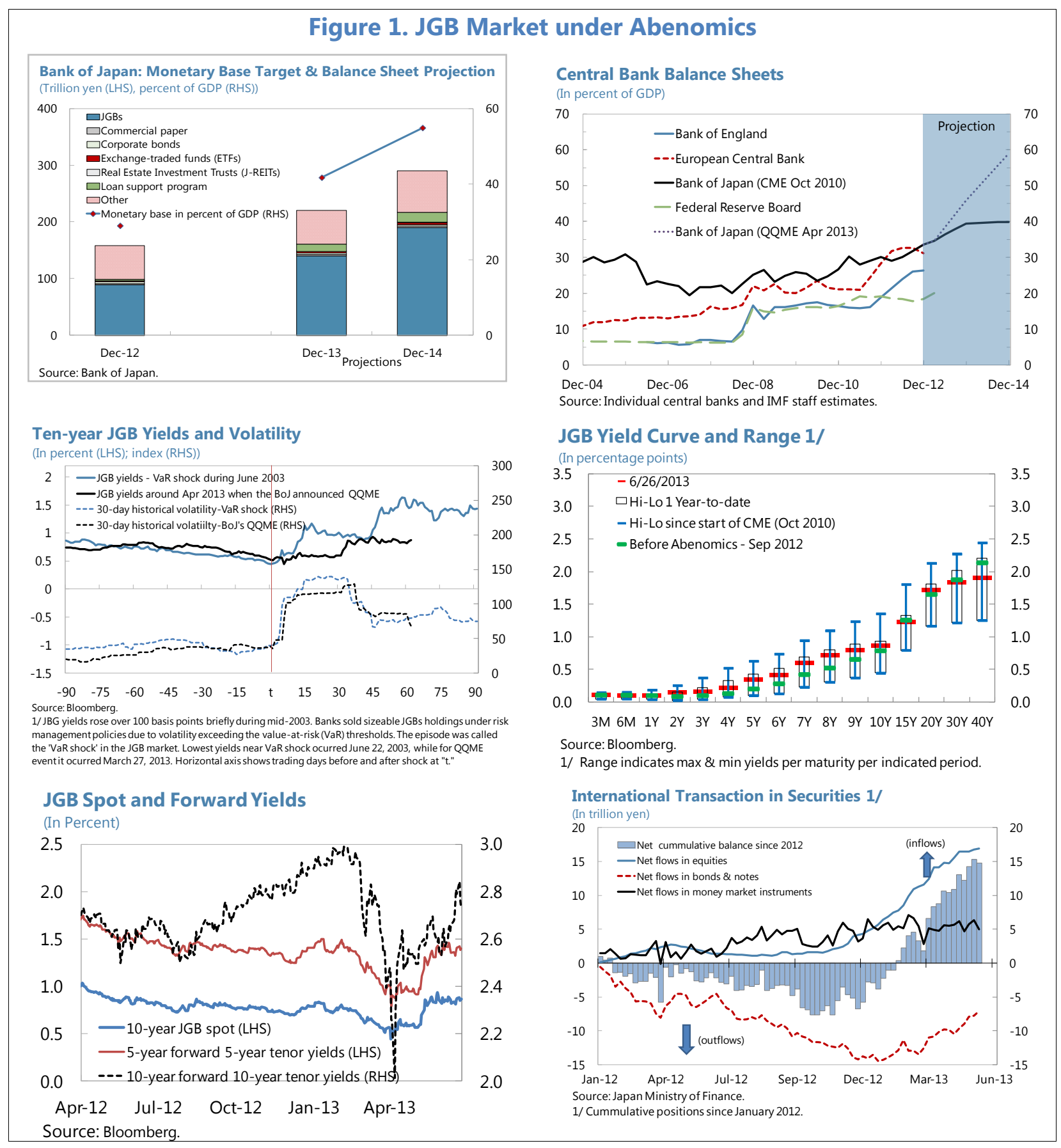

The new policies will likely have a fundamental impact on domestic debt markets and financial stability. IMF (2013) illustrates potential implications on growth, inflation, and government debt of three possible scenarios - a complete policy scenario, an incomplete policy 
scenario, and a pre-Abenomics baseline scenario. ${ }^{3}$ Under the complete policy scenario, the authorities adopt ambitious structural reforms that raise trend growth from 1 to 2 percent over the next decade. Along with QQME and medium-term fiscal consolidation, the complete package would align inflation expectations quickly, leading to lower government funding needs. In contrast, under the incomplete package scenario, inflation expectations adjust in a sluggish manner to QQME, possibly because of the lack of a structural reform program, requiring further fiscal stimulus to close the output gap and boost inflation in the near term. The lack of mediumterm fiscal adjustment and a rising risk premium result in higher government debt and the eventual decline in output to below the pre-Abenomics baseline (Table 1). Based on the same scenarios, the paper explores the implications of complete and incomplete policy packages on long-term interest rates and banks' balance sheet exposures.

Table 1. Description of Analytical Scenarios on the Policy Package under Abenomics

\begin{tabular}{|l|l|}
\hline \multicolumn{1}{|c|}{ Scenarios } & \multicolumn{1}{c|}{ Description } \\
\hline 1. Baseline & $\begin{array}{l}\text { The pre-Abenomics baseline is taken as the December } 2012 \text { forecasts in } \\
\text { the World Economic Outlook. }\end{array}$ \\
\hline $\begin{array}{l}\text { 2. Complete policy } \\
\text { package }\end{array}$ & $\begin{array}{l}\text { Ambitious structural reforms are taken to raise the trend long-term } \\
\text { growth to 2 percent (IMF 2013). }\end{array}$ \\
& $\begin{array}{l}\text { Inflation expectations are aligned to the inflation target quickly within } \\
\text { the timeframe forecast by the BoJ. }\end{array}$ \\
\hline $\begin{array}{l}\text { 3. Incomplete policy } \\
\text { package }\end{array}$ & $\begin{array}{l}\text { Medium-term fiscal adjustments are undertaken to bring down debt in a } \\
\text { downward trajectory. }\end{array}$ \\
\hline & $\begin{array}{l}\text { Long-term growth remains stagnant without structural reforms. } \\
\text { Inflation expectations align only gradually in a sluggish manner. }\end{array}$ \\
\hline
\end{tabular}

\section{OUTLOOK FOR INTEREST RATES UNDER ABENOMICS}

\section{A. Literature Review}

Several studies have tried to explain the seemingly weak empirical relationship between public debt and long-term yields in Japan resorting to a number of different temporary causes. Tokuoka (2010) argues that, although several factors (see below) have contributed to low JGB yields, the market's capacity to absorb public debt is likely to diminish as the population ages. Gross household financial assets could fall short of the rising public debt by FY2015FY2020. In a follow-up paper, Lam and Tokuoka (2011) examine financial risks and possible triggers in the JGB market. Hoshi and Ito (2012) illustrate various scenarios on how long-term JGB yields can remain low and stable (defying gravity) and conclude that, as JGB financing will have to rely more on foreign investors, yields will likely rise unless drastic fiscal adjustments are put in place. Baba (2012) argues that the turning of Japan's current account balance from surpluses into deficits will exert upward pressures on JGB yields. Ichiue and Shimizu (2012)

\footnotetext{
${ }^{3}$ See IMF Country Report No. 13/253 (Box 1) for a detailed discussion of the potential effects of these scenarios on growth, inflation and debt.
} 
estimate factors driving long-term interest rates across advanced economies and apply the results to Japan and the United States. They find that demography and growth play a key role in determining long-term rates but their analysis does not fully account for recent policy changes and how those factors may evolve over the long term.

The most common factors cited as contributing to low and stable JGB yields are (Figure 2):

- Sustained deflation and low potential growth.

The outlook of long-term JGBs financing is influenced by real growth and inflation dynamics. Persistent deflation and sluggish growth over the last two decades have contributed to a sharp decline of nominal yields and kept real yields relatively higher. In addition, policies that strengthen or weaken the growth and inflation paths would likely affect long-term yields.

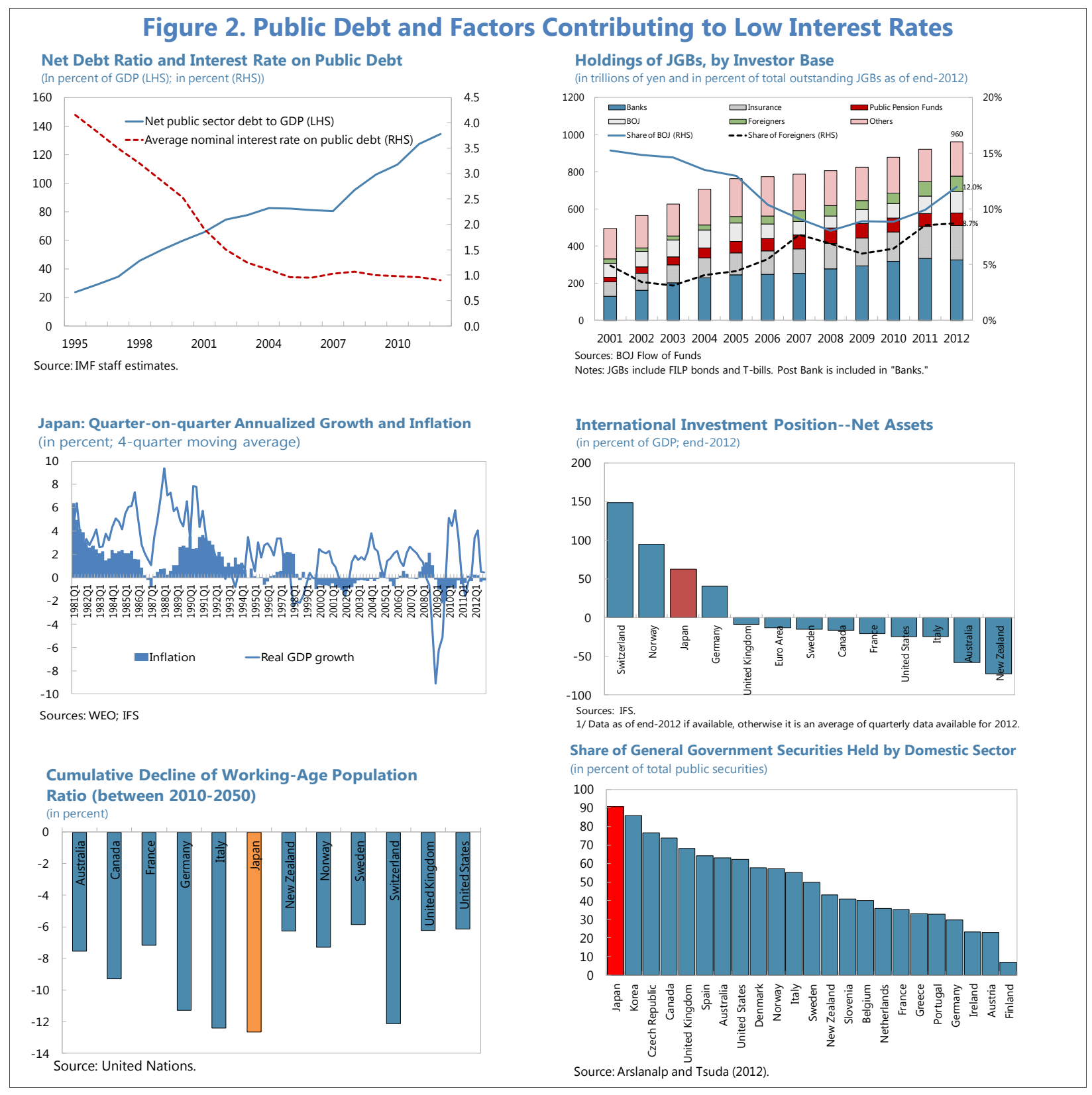


- Expectations of future fiscal adjustments - The total tax-to-GDP ratio for Japan is still low at around 30 percent (including payment into the social security system) and has room to increase to a level comparable to European countries to narrow the financing gap in government finance. This might create the public perception that although deteriorating fiscal conditions are likely to exert an upward pressure on long-term rates, drastic fiscal reforms could be taken to restore fiscal sustainability before the public debt exceeds private sector savings.

- External surpluses - Unlike most other advanced economies, Japan has sizeable net foreign assets (over 50 percent of GDP) and has run a current account surplus over the past decade, supported by steady and large net-income flows. This reduces the reliance on foreign investors in financing JGBs, and combined with stable investor base (see below), tend to keep yields low and stable.

- Large private stock of savings_-Japan had enjoyed high household saving rates (over 10 percent) until around 1999 when they began to decline sharply. This contributed to a large accumulation of household financial assets, helping to finance the build-up of public debt. In addition recent large surpluses in the corporate sector have played a supporting role in channeling funds to finance JGBs.

- Population aging - Population aging will reduce labor force participation and potential growth. At the same time, elderly households tend to have a higher risk aversion and home bias and prefer holding safe assets such as JGBs, although the elderly tend to have lower saving rates. ${ }^{4}$ More than half of the households' financial assets are held in the form of currency and deposits. This is likely to exert downward pressure on long-term interest rates.

- Stable investor base - Over 90 percent of JGBs are held by domestic investors, which has not changed substantially during the global financial crisis. This is in contrast to other advanced economies, where rising sovereign debt has been met with an increasing reliance on foreign investors, possibly posing a higher refinancing risk. This advantage, however, needs to be weighed against potential vulnerabilities from increasing sovereign-financial linkages in Japan.

\section{The development of long-term sovereign yields has also been a key area in policy} discussions in other major advanced economies. There is a growing concern that long-term yields across advanced economies (e.g., United Kingdom, and the United States) have been at historical lows that diverge from the levels consistent with economic fundamentals, largely attributed to the unconventional monetary policies of central banks. Andritzky (2012) and Arslanalp and Poghosyan (2013) find that net foreign sales and purchases of government debt have played a key role in determining long-term sovereign bond yields. The impact of fiscal positions on sovereign yields after the global financial crisis appears to be more modest in cross-

\footnotetext{
${ }^{4}$ Hasegawa and Lam (2011) examines the saving behavior across age and cohort groups using household survey data and finds that over the medium term, the effect of risk aversion on asset allocation toward government securities among the elderly is likely to exceed the impact of a reduction of elderly saving rates.
} 
country empirical studies (Laubach 2003, Ardagna, Caselli, and Lane 2004, Alper and Forni 2011, Poghosyan 2012, Ichiue and Shimizu 2012). ${ }^{5}$

\section{B. A Panel Analysis on the Determinants of Long-Term Interest Rates}

The empirical analysis builds on the current literature on the determinants of long-term yields across advanced economies. Countries in the panel estimation include Australia, Canada, France, Italy, Germany, Japan, New Zealand, Norway, Sweden, Switzerland, the United Kingdom, and the United States. Euro area countries other than Germany are excluded as interest rates across euro area were aligned until the euro area debt crisis broke out (in some specification, France and Italy are included as well for robustness check on the estimated results). ${ }^{6}$ The sample period spans from 1990 to 2012 using annual data. The dynamic panel estimation is expressed as:

$$
\begin{aligned}
E_{t} i_{t+\tau, j}=c_{j}+ & \beta_{1} E_{t} E X T_{t+\tau, j}+\beta_{2} E_{t} F I S_{t+\tau, j}+\beta_{3} E_{t} D G_{t+\tau, j}+\beta_{4} E_{t} y_{t+\tau, j} \\
& +\beta_{5} E_{t} \pi_{t+\tau, j}+\beta_{6} \operatorname{InvBase}_{t, j}+\varepsilon_{t, j}
\end{aligned}
$$

with variables expressing expectations at time $t$ for $\tau$ period ahead; $j$ denotes country in the crosssection group. The dependent variable $E_{t} i_{t+\tau, j}$ is the nominal forward rate of 5-10 years ahead (that is, 5-year forward of 5-year tenor rates). ${ }^{7}$ EXT and FIS are vectors of variables related to external and fiscal conditions both in terms of flows and stocks. Variables for external conditions include the current account balance and the net external balance as a percent of GDP. Fiscal variables include (i) net government debt and/or public assets as a percent of GDP as stock variables; and (ii) primary balance or cyclical fiscal balance as a percent of GDP as flow variables. A dummy variable is introduced to interact with fiscal variables to assess whether structural differences occurred after the global financial crisis given that sovereign bonds in some countries were perceived as safe haven assets. $D G$ is the demographic factor measured by the (annualized) growth rate of the working-age population ratio. Variables $y$ and $\pi$ refer to real growth and inflation. The regression extends beyond other empirical studies by analyzing the role of the investor base in affecting long-term sovereign yields. InvBase refers to the portion of sovereign bonds held by central banks, foreign nonofficial entities, or domestic financial institutions depending on the specification.

\footnotetext{
${ }^{5}$ Earlier empirical studies on the impact of fiscal deficits include Baldacci, Gupta, and Mati (2009) on emerging markets; Faini (2006) on Europe; Hauner and Kumar (2006) on G7 countries; Engen and Hubbard (2004) and Laubach (2003) on the United States; Kinoshita (2006), and Ardagna, Caselli, and Lane (2004) on OECD countries. Brook (2003) provides a comprehensive list of studies with estimates. These empirical studies, which examined the impact of deficits or debt on long-term government bond yields, find that a 1 percentage point increase in the fiscal deficits to GDP ratio would raise long-term yields by 10-60 basis points. Studies based on general equilibrium structural models find that a 1 percentage point rise in the public debt to GDP ratio would raise yields by 10 basis points at most.

${ }^{6}$ Regression estimates for two groups of countries are included. Group 1 includes all countries except France and Italy as they are in the euro area broadly represented by Germany, while Group 2 includes both France and Italy.

${ }^{7}$ Data on 5-year forward of 10-year tenor rates or 10-year forward of 10-year tenor rates are not available for long periods dating back to 1990 and are difficult to be estimated without 15-year or 20-year sovereign bonds in several countries.
} 
Data for the empirical studies are obtained from various sources. The estimation uses 6-10 years ahead for demography variables and at least 2 years ahead for growth, inflation, fiscal and external conditions from the Consensus Forecast and World Economic Outlook. The descriptive statistics are in Table 2. A longer time horizon $\tau$ for the dependent variable would be preferable, but the choice was limited by data availability. The estimation uses the Arellano-Bond dynamic panel estimator with a maximum of four lags. The results include four sets of specifications ( 1 to 4, Table 3), each including a specific group of investors in government securities (the central bank, domestic financial institutions, domestic entities, and foreign nonofficial investors). For each set of specifications, additional estimates are provided for different country groups and different explanatory variables for the robustness check.

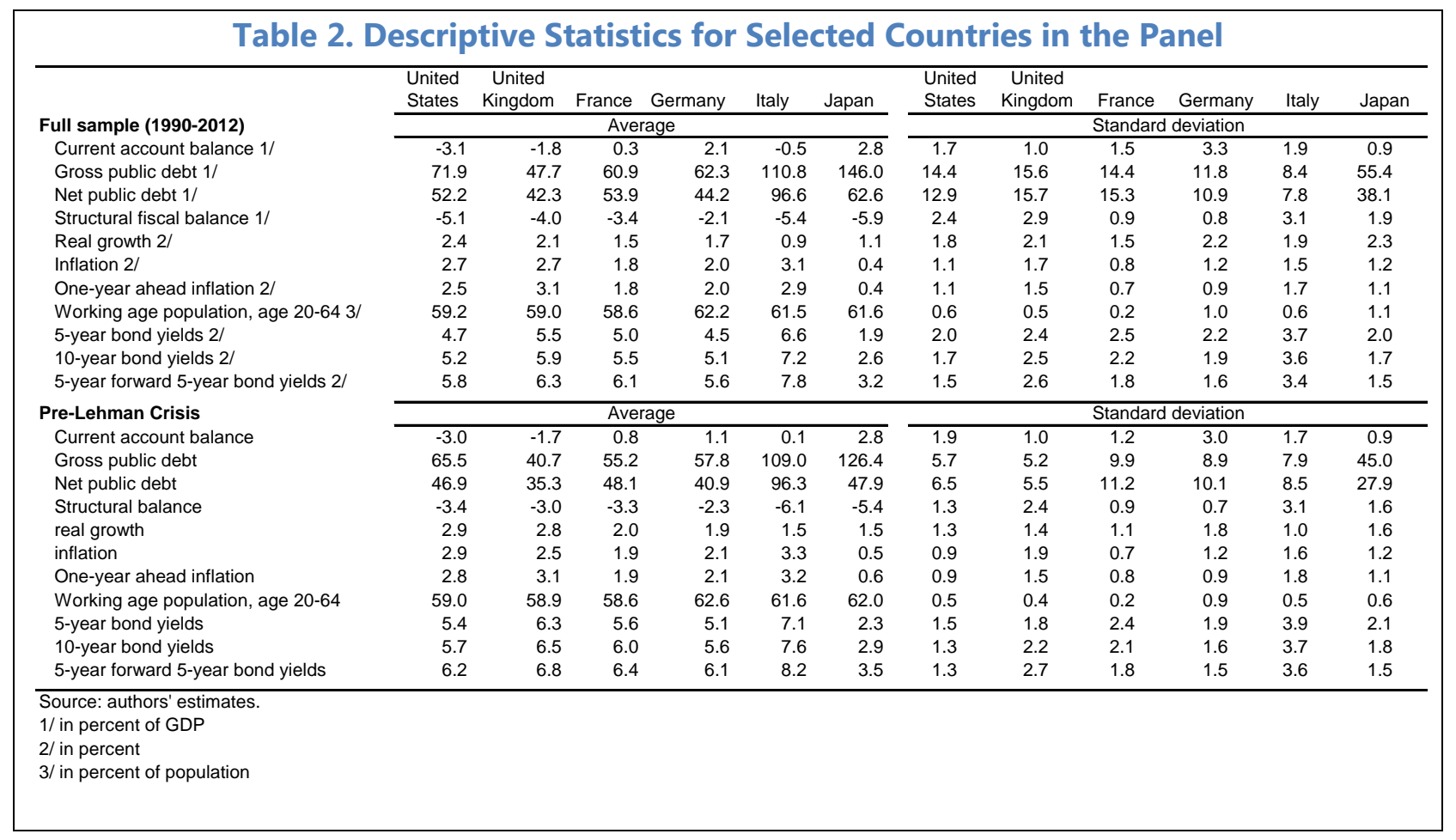

\section{Estimation results.}

a. Fiscal conditions are one of the key contributing factors to long-term sovereign yields across specifications in the panel. Model estimates imply that, a 1 percentage point rise in net government debt to GDP would increase the long-term yields by $2-4$ basis points over the sample. However, the rise appears smaller by one-third to one-half after the global financial crisis, perhaps reflecting higher global risk aversion and therefore greater demand for safe government securities. Among fiscal variable, cyclical or primary fiscal balances, however, are not statistically associated with long-term rates unless the specification includes gross government assets. ${ }^{8}$ The stock of net public debt appears to

\footnotetext{
${ }^{8}$ The limited effect of fiscal balances on yields may partly be explained by the Ricardian equivalence, which tends to be more evident in major advanced countries with higher level of debts.
} 
be more influential in determining long-term interest rates, but the effect is likely to be nonlinear depending on the level of public debt (see caveats below).

b. External conditions appear to affect long-term rates but are seldom statistically significant. This runs counter to the idea that Japan would run into a fiscal crisis when the current account moves into deficits. The estimates suggest that government debt may become unsustainable even when the current account stays in surplus if domestic savers refuse to finance the public debt at a low rate. On the contrary, a fiscal crisis may not happen even when the current account moves into deficits, if the change is the result of strong direct investment inflows that raise growth potential. Despite limited evidence on the role of trade deficits on long-term interest rates, deteriorating external conditions in Japan would imply a heavier reliance of foreign investors in financing public debt.

c. Inflation and growth expectations are also key factors in affecting long-term rates. The estimated coefficients for inflation expectations are strongly significant, as expected, and in many specifications the coefficients are not statistically different from one, which is consistent with economic theory. In that context, real forward rates (nominal net of inflation expectations) are also used as dependent variable for robustness purposes. The sign of coefficients for most explanatory variables remain broadly similar. Volatility of inflation expectations does not appear to affect the level of long-term rates. Coefficients on real growth expectations across specifications are also statistically significant and have an expected positive sign. As Abenomics aims to exit deflation and raise long-term growth, a successful policy package could likely raise growth and inflation expectations that would increase the long-term nominal yields. Nonetheless, higher growth would also help mitigate the rise in public debts, offsetting some of the rise in nominal yields.

d. A reduction in the working-age population tends to reduce the long-term interest rates, possibly due to preference towards safer assets as the population ages. ${ }^{9}$ The magnitude appears to be significant and its contribution to the level of the interest rate is large.

e. The composition of the investor base for government securities is important for longterm interest rates. Higher holdings by domestic entities tend to lower interest rates, but the cross-country estimates show that this reduction is mostly driven by central banks' holdings rather than holdings by domestic financial institutions. On the other hand, higher holdings of government securities by the foreign nonofficial sector tend to raise yields, but this does not seem to be statistically significant.

In sum, empirical results suggest that the upward pressure on long-term JGB yields from deteriorating fiscal conditions has been offset so far by other factors, including a stable domestic investor base with a preference for safe assets and increased purchases by the BoJ, but these effects are likely to decline over the medium term.

\footnotetext{
${ }^{9}$ Population aging could lead to an aggregate increase in the rate of time preference, given the remaining life expectancy as a whole is declining, but that effect may be more than offset by the higher preference on safer assets.
} 


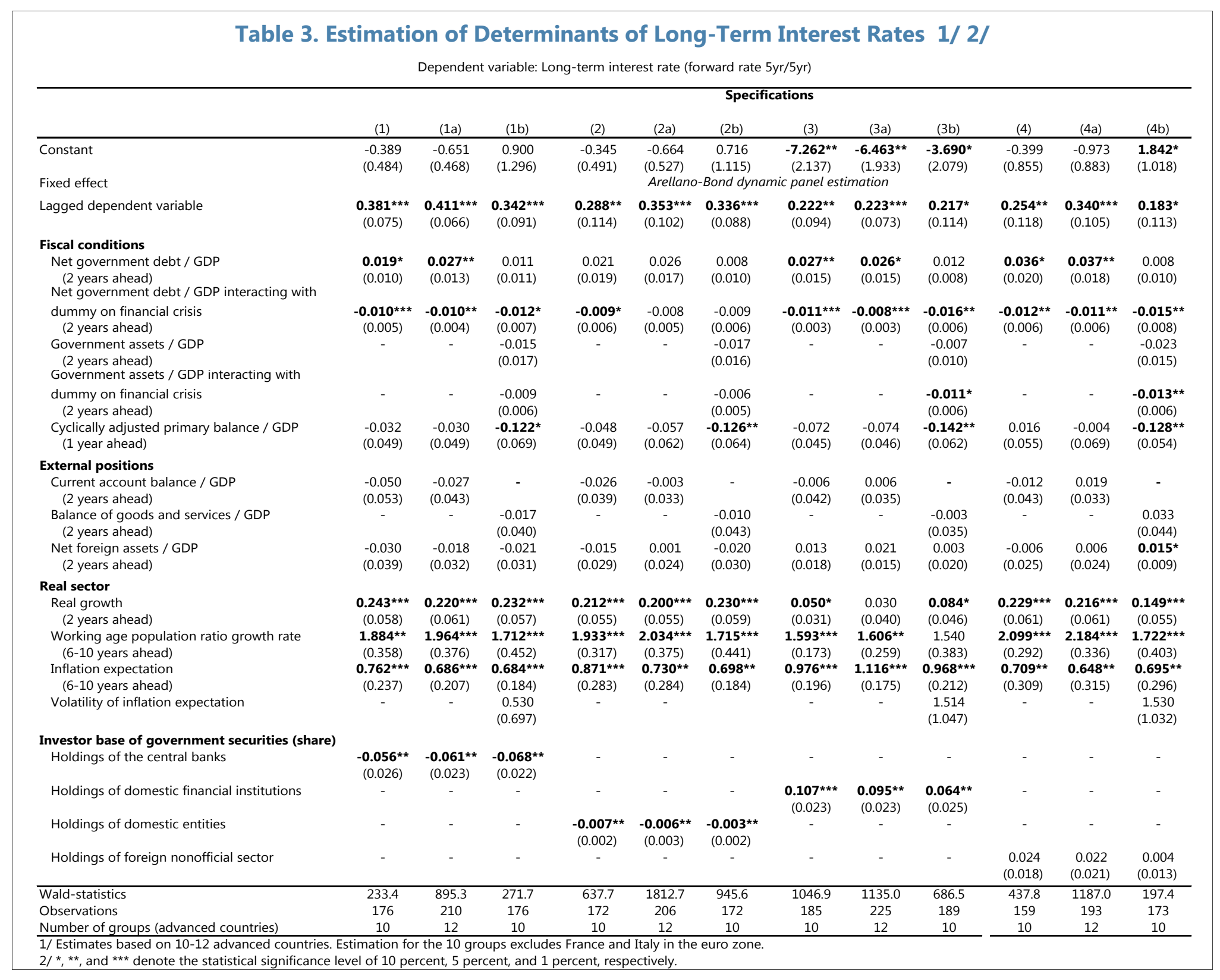




\section{Scenario Analysis}

The estimates allow a quantitative assessment of the extent to which each factor drives longterm rates over time (Figure 3). As the primary interest is the evolution of long-term rates under the QQME and rising public debts, estimates from specification (1) are used to obtain the contributions of each factor. The analysis uses the baseline growth and inflation forecasts from the December 2012 World Economic Outlook, which forecast potential growth and inflation reaching 1 percent and 2 percent, respectively, under the baseline. Medium-term external positions are also obtained from the World Economic Outlook, while long-term forecast of current account balances are taken from Hoshi and Ito (2012). The fiscal deficits and debt profiles are obtained from the IMF's estimates under the debt sustainability analysis as in IMF (2013). Demographic projections are taken from the United Nations.

Based on current policies, deteriorating fiscal conditions over the medium term are likely to exert upward pressures on long-term interest rates (Figure 3 upper charts). The decomposition suggests that low growth, disinflation, and aging of the population since the mid2000s have contributed to the low and stable long-term rates, which have more than offset the impact of the deterioration in fiscal conditions. The sizeable purchases by the $\mathrm{BoJ}$ are likely to keep long-term rates lower by $70-150$ basis points for the next few years under the QQME. Long-term rates, however, are expected to rise to $4 \frac{1}{2}$ percent by 2020 and nearly $5 \frac{1}{2}$ percent by 2030. This represents a 4 percentage points increase in long-term yields from 2012 to 2030 , to which deterioration in fiscal conditions would contribute $3 \frac{1}{2}$ percentage points (about 3 percentage points from the projected rise in the net public debt ratio from 134 percent in 2012 to near 210 percent of GDP by 2030 and another $1 / 2$ percentage point from larger fiscal deficits). Inflation and higher growth would add another 2 percentage points and shrinking external surpluses a further $1 / 2$ percentage points. The net increase, however, would be much smaller because of population aging (-11/4 percentage points), BoJ purchases ( $-3 / 4$ percentage points), and other factors.

Under a complete policy package, the long-term interest rates are likely to remain stable in the long run (Figure 3 lower charts). As discussed in Section II, the complete policy package assumes credible fiscal policy adjustments and structural reforms that will achieve a declining public debt trajectory and higher potential growth (IMF 2013). ${ }^{10}$ In addition, this analysis further assumes no further monetary easing by the BoJ after achieving the inflation target. In this regard, higher growth and lower holdings by the BoJ would push interest rates up slightly over the medium term, relative to the baseline, while the near-term interest rates remain low and stable. Notably, lower public debt ratios, together with long-term primary surpluses, would keep longterm nominal interest rates at stable levels at about 3-4 percent over the long term. This implies that real interest rates would be in the range of 1.2-1.9 percent.

\footnotetext{
${ }^{10}$ Structural reform measures include addressing labor market duality, raising labor participation of women and the elderly, advancing SME restructuring through less barriers of firm entries and phasing out excessive credit guarantees, and providing more risk capital for start-ups.
} 


\section{Figure 3. Decomposition of Long-Term Interest Rates}

\section{A. Based on current policies}
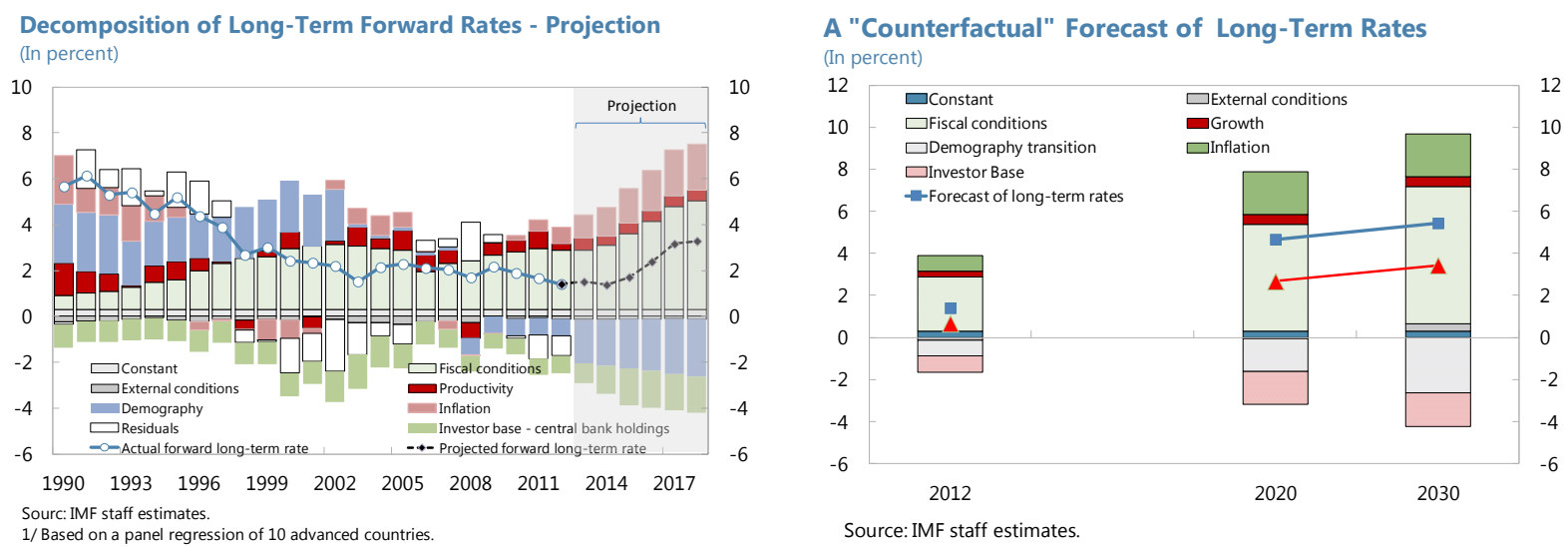

B. Based on complete polices
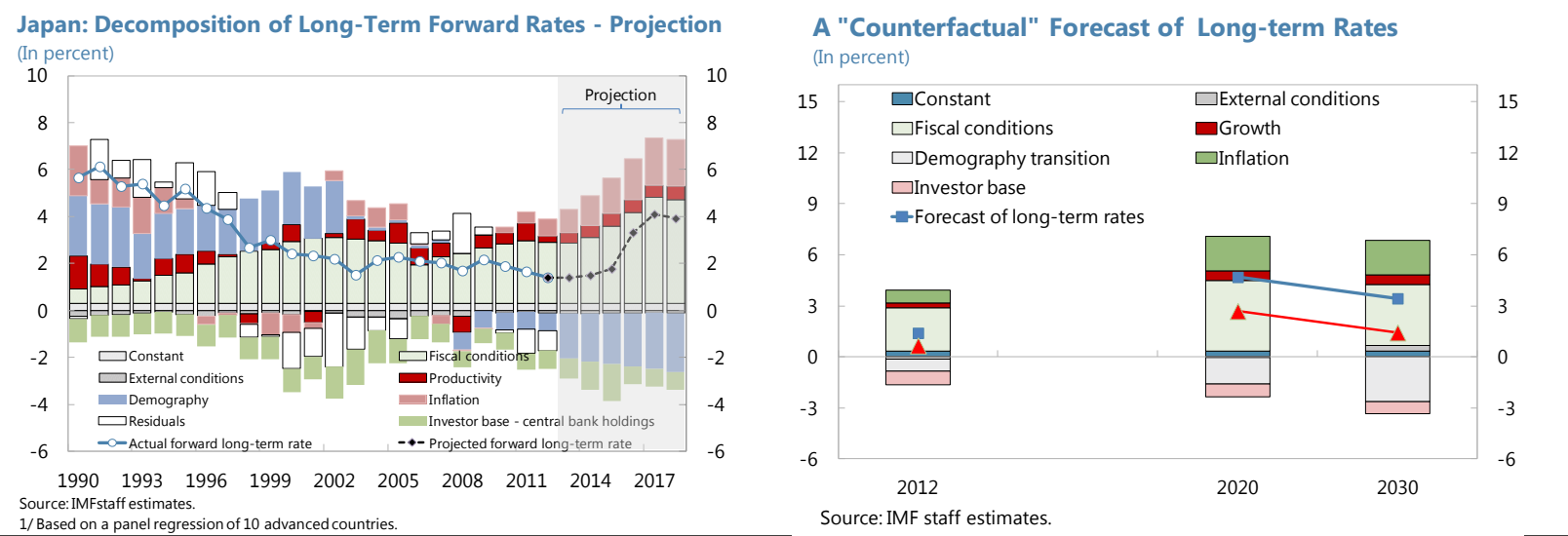

Another way to highlight the importance of fiscal conditions for JGB markets is to assess the domestic market's financing capacity (Figure 4). Unless a complete policy package is implemented, household financial assets are likely to fall short of financing the rising government debt by the next decade. As such, JGB financing would need to rely more heavily on foreign investors that would have implications on bond yields. An update of Tokuoka (2010) on the outlook for financing JGBs based on the three scenarios illustrates that:

- Under the incomplete policy scenario, general government gross debt would exceed gross financial assets of households by the mid-2020s, about two to three years earlier than under the pre-Abenomics baseline. Even with a conservative assumption that the household saving rate would stay constant (instead of declining as the population ages), government debtrising to around 310 percent of GDP by 2030 under the incomplete scenario-will eventually 
exceed household financial assets. ${ }^{11}$ The precise timing is subject to a large degree of uncertainty depending on growth and interest rates going forward.

- Under the complete policy scenario, gross government debt will rise but at a much more modest pace over the medium term, peaking at around 250 percent of GDP. The debt level in 2030 would still remain below gross financial assets of households.

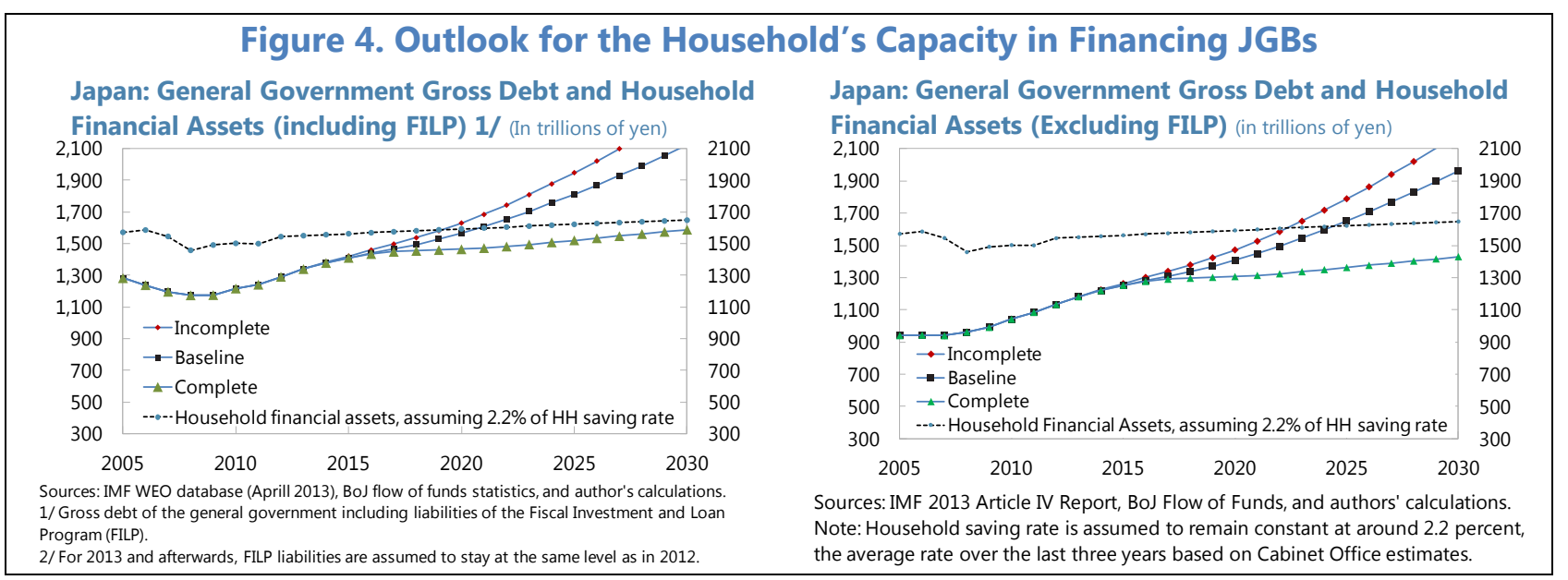

The empirical estimation and subsequent projections are subject to three main caveats.

First, under the new monetary framework, the impact on long-term interest rates may behave differently than predicted by the reduced-form model, which uses the estimated coefficients from historical correlations. In addition, the estimates focused on long-term interest rates and cannot account for short-term volatility in JGB markets. Second, the panel estimation may not fully capture all determinants of long-term interest rates and the debt profile, particularly those factors unique to Japan, such as strong home bias, and the net creditor status in the international investment position. Nonetheless, the estimation appears to provide a reasonably good fit for Japan and has shown that some factors, such as the large domestic holdings of JGBs, low growth, and persistent deflation have contributed to low yields despite rising public debt. Third, the explanatory variables could have a nonlinear or a threshold effect on long-term rates that is not captured in the estimation and projection. For instance, interest rates could be subject to abrupt spikes rather than a gradual rise if there was a severe loss of confidence in public debt and/or fears of debt monetization by the central bank. In those cases, a general equilibrium framework that accounts for such feedback may be more appropriate. The influence of external conditions may also play a larger role in determining long-term rates if trade deficits are combined with a slower build up of net assets in the international investment position. Similarly, extensive

\footnotetext{
${ }^{11}$ The scenarios do not take into account the assets of the private corporate sector. Those are large at around 165 percent of GDP at end-2012. However, in net terms, the private corporate sector has negative net assets given total liabilities of 218 percent of GDP. As such, we assume corporate savings will continue to be used mainly to deleverage their own balance sheets. The inclusion of debt related to the fiscal investment and loan program (FILP) will move the crossing time closer by about four years.
} 
holdings of government bonds by domestic financial institutions may add to higher fiscal and financial linkages that would eventually add to the risk premium.

\section{OUTLOOK FOR INTEREST RATE RISK EXPOSURES OF JAPANESE BANKS UNDER} ABENOMICS

\section{A. The Role of Japanese Banks in the JGB Market}

Japanese banks have played a key role in the JGB market, essentially serving as residual buyers of JGBs given their role as primary dealers and market makers. Japanese banks have purchased about $¥ 200$ trillion (about 40 percent of 2012 GDP) of government debt since 2000 . As Japan Post Bank has been reducing its JGB purchases, new issuances of JGBs have been picked up mostly by private domestic banks in particular major and regional banks ("domestic licensed banks"). Meanwhile, insurance and pension funds have steadily increased their JGB holdings to match their long-term liabilities at a pace of around $¥ 9$ trillion per year, while social security funds have started to reduce their holdings in the last four years to pay out retiring pensioners at about $¥ 4$ trillion per year (Figure 5). Following the global financial crisis, the BoJ has become a net buyer of JGBs and will continue to play an increasing role under the QQME (by end-2014, the BoJ will hold about $¥ 190$ trillion in JGBs). In contrast, foreign investors have played a limited role in the JGB market with cumulative purchases of less than $¥ 50$ trillion since 2000 . Other investors do not play a significant role in the JGB market (Figure 5).

Accordingly, Japanese banks' purchases of JGBs has been determined to a large extent by the following factors: (i) net issuance of JGBs; (ii) social security fund net purchases of JGBs; (iii) BoJ net purchases of JGBs; and (iv) foreign net purchases of JGBs. More specifically, the following stylized equation can explain most of the variation in Japanese banks' holdings of JGBs since 2000 (bottom charts of Figure 5).

$$
B_{t}=B_{0}+D_{0, t}-S S F_{0, t}-C B_{0, t}-F O R_{0, t}-a l p h{ }^{*} t
$$

where $B_{t}$ represent Japanese banks' JGB holdings at time $t ; D_{0, t}$ represents the cumulative net issuance of JGBs between 2000 and $t ; S S F_{0, t}, C B_{0, t}$, and $F O R_{0, t}$ represent the cumulative net purchase of JGBs by social security funds, the BoJ, and foreigners, respectively; and alpha represents a time trend that captures the secular purchase by other investors, in particular insurance and pension funds (i.e., alpha is equal to $¥ 9$ trillion). It seems unusual at first glance that JGB yields or other macro variables do not enter into the equation, but the equation captures the dynamics because (i) it simply relies on the supply and demand balance in the JGBs market; (ii) Japanese insurance and pension funds have had a historically stable demand for JGBs due to their asset liability matching policies; and (iii) other domestic non-banks, including mutual funds, are negligible buyers of JGBs (top charts of Figure 5). 
Figure 5. Demand and Supply Balance in the JGB Market

A. Cumulative Net Purchase of JGBs by Investor Type, 2000-12 1/

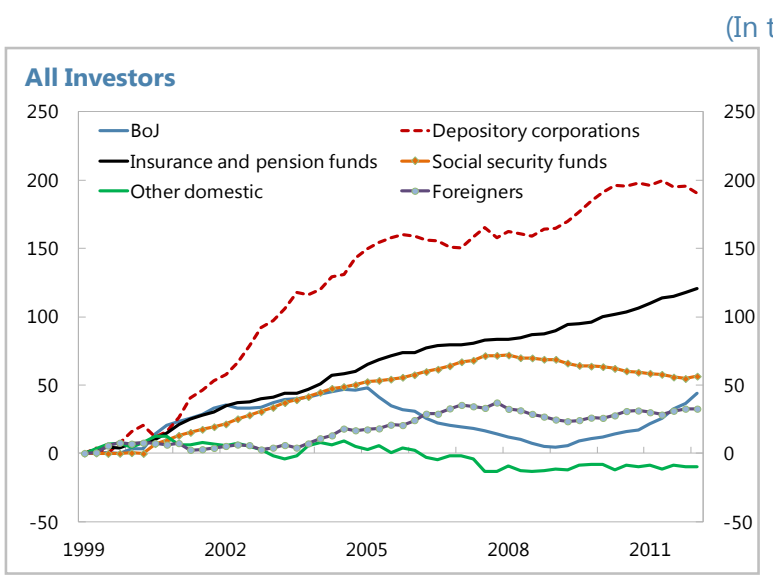

(In trillion yen)

B. Actual and Predicated Cumulative Net JGB Purchase by Depository Corporations 2/ (In trillion yen)

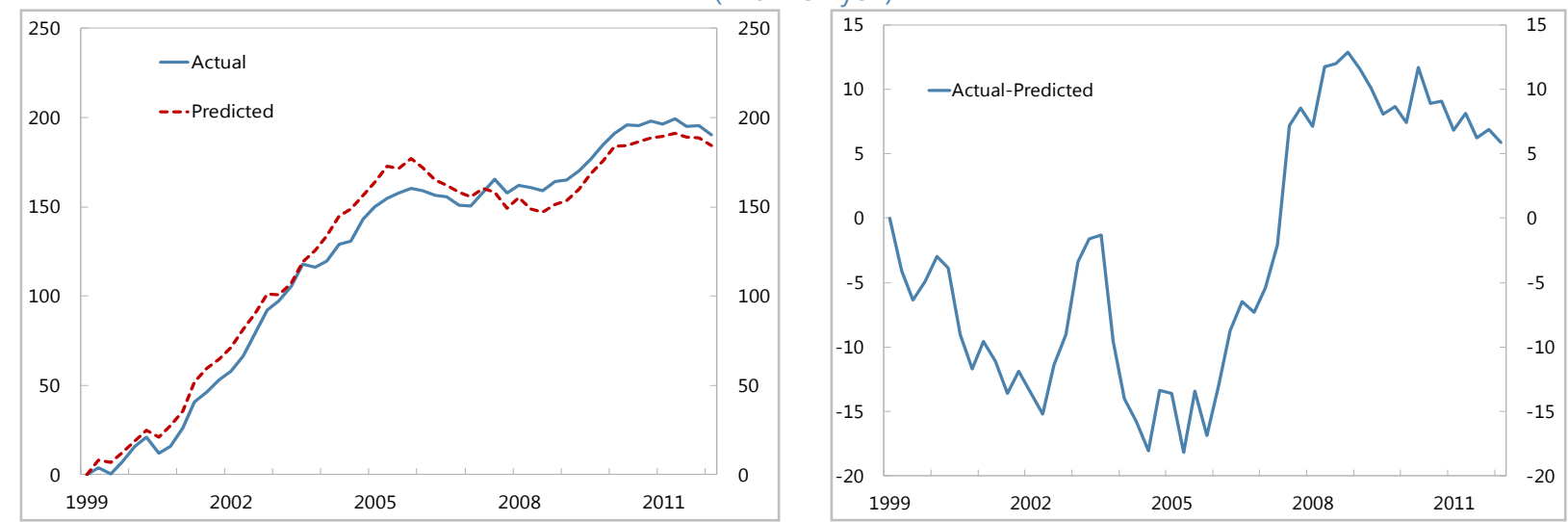

Sources: Bank of Japan Flow of Funds statistics, Japan Post Bank, and IMF staff estimates.

1/ Depository corporations include Japan Post Bank, with the figures after 2007 estimated from company reports. Insurance funds include Japan Post Insurance. Social security funds include the Government Pension Investment Fund (GPIF). Other domestic includes households and corporations. Domestically-licensed banks include major and regional banks.

2/ Predicted purchases of JGBs by depository corporations are based on (i) total net issuance; (ii) social security fund purchases; (iii) Bank of Japan purchases; and (iv) foreign purchases.

This stylized relationship can be used to project Japanese banks’ potential JGB holdings under various scenarios. One advantage of this approach is that the relationship requires very little information about more general economic and financial variables. Importantly, out of the four variables in the equation, two of them are set by policy ( $D$ and $C B$ ) and can be reasonably anticipated, while the other two ( $S S F$ and $F O R$ ) have relatively low variance and can be projected based on reasonable assumptions derived from past trends. Hence, we use this relationship to construct the scenarios discussed in the next section. One possible shortcoming of this approach is that under Abenomics, net purchases of JGBs by insurance and pension funds may deviate from the historical trend (i.e., alpha may change), as they seek alternative investment opportunities including foreign assets. Similarly, the government pension fund (GPIF) has recently made changes to its investment strategy. However, the immediate impact of such 
changes appears to be small and the demand for JGBs by these investors are likely to remain strong given their investment mandates of asset-liability management.

\section{B. Scenario Analysis}

\section{Illustrative scenarios are presented to highlight how Japanese banks' JGB holdings and} interest rate risk exposures may change. As discussed in Section II (Table 1), three scenarios are considered: (i) a baseline pre-Abenomics scenario; (ii) a complete Abenomics package under which QQME, fiscal consolidation, and ambitious structural reforms lead to lower government funding needs and higher growth; and (iii) an incomplete Abenomics package under which inflation expectations adjust in a sluggish manner, possibly because of the lack of a structural reform program, requiring further fiscal stimulus to close the output gap and boost inflation in the near term. Based on these scenarios and the JGB supply-demand relationship discussed earlier, Japanese banks' holdings of JGBs are projected based on the assumed fiscal policy path $(D)$, BoJ's QQME announcements $(C B)$, and assumptions on the investment behavior of social security funds $(S S F)$ and foreigners $(F O R)$.

\section{In particular, Japanese banks' JGB holdings are projected for 2013-17 as follows (Table 4):}

- D. Cumulative net issuance of JGBs over the medium term is based on IMF general government gross debt projections under the three scenarios (Table 1). In all scenarios, general government debt is assumed to be issued as follows: 75 percent in JGBs, 20 percent in treasury bills, and 5 percent in local government bonds, in line with the broad pattern of debt issuance in recent years.

- $\quad C B$. The BoJ's net JGB purchases over 2013-14 are projected based on the April 2013 policy announcement ( $¥ 50$ trillion each in 2013 and 2014), and its holdings are assumed to be constant thereafter (i.e. we assume the BoJ will roll over any JGBs maturing in their portfolio over the following three years). Under the pre-Abenomics scenario, BoJ's JGB purchases are projected based on the Open-Ended Asset Purchasing Method introduced in January 2013.

- $S S F$. Social security funds are assumed to remain net sellers of JGBs under current demographic trends by $¥ 4$ trillion per year.

- FOR. The foreign share of JGBs is projected to increase from $41 / 2$ percent at end-2012 to 7 percent by end-2017 under complete policies, but fall to 2 percent under incomplete policies, as foreign investors become more concerned about fiscal sustainability. The figures of 7 percent and 2 percent represent the highest and lowest foreign share registered in the JGB market since 2000 , respectively. 
Table 4. Projected Net Purchases of JGBs, 2013-17

(Annual average, in trillion yen)

\begin{tabular}{lccc}
\hline & Pre-Abenomics & $\begin{array}{c}\text { Abenomics: } \\
\text { complete } \\
\text { package }\end{array}$ & $\begin{array}{c}\text { Abenomics: } \\
\text { incomplete } \\
\text { package }\end{array}$ \\
\hline Net JGB issuance & 25.9 & 25.3 & 28.7 \\
BoJ & 14.7 & 20.0 & 20.0 \\
Depository corporations & 5.0 & -5.5 & 6.9 \\
Insurance and pension funds & 9.0 & 9.0 & 9.0 \\
Social security funds & -4.0 & -4.0 & -4.0 \\
Other domestic & 0.0 & 0.0 & 0.0 \\
Foreigners & 1.2 & 5.8 & -3.3 \\
\hline
\end{tabular}

Source: IMF staff projections.

Notes: The BoJ net purchases of JGBs are 50 trillion yen each in 2013 and 2014 and zero afterwards. Net purchases by insurance and pension funds are based on historical trends. Net purchases by social security funds is based on trends in the last four years.

\section{A final simplifying assumption is that net purchases of JGBs and other domestic bonds by major and regional banks respectively take place proportional to their current holdings.}

That essentially means that, under the scenarios, major and regional banks maintain their relative shares in the JGB, local government bond, and corporate bond markets (Section V-C discusses some cases when this may not hold). More specifically, major and regional banks' JGB holdings are projected based on the relative share assumption and the projected JGB holdings of Japanese banks as a whole, as discussed earlier. A similar approach is used for local government bonds. ${ }^{12}$ Finally, corporate bond holdings in major and regional bank balance sheets are projected forward in line with nominal GDP. Figure 6 summarizes the results of these projections for the preAbenomics scenario.

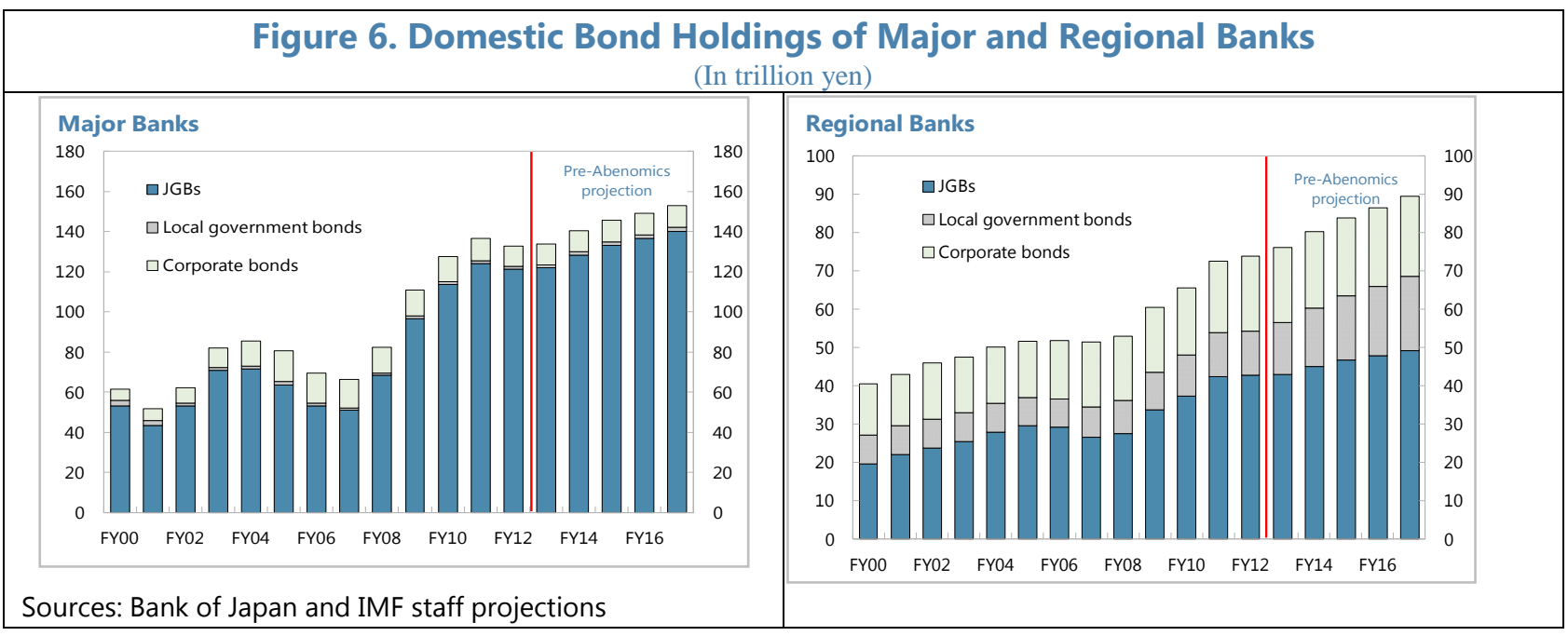

\footnotetext{
${ }^{12}$ The BoJ does not hold local government bonds. Foreign purchases of local government bonds are negligible, while social security funds have not been buying local government bonds in recent years. We therefore assume Japanese banks will be the main buyers of local government bonds in the projections.
} 
The interest rate risk exposure of Japanese banks is calculated as mark-to-market losses to Tier I capital from a hypothetical 100-basis-point parallel rise in the domestic yield curve, in line with the methodology of the BoJ in the Financial System Report. ${ }^{13}$ This is reflected in the equation below. Going forward, we assume a gradual reduction in the duration of bank holdings of JGBs given the BoJ is expected to expand their duration of JGB holdings under the QQME. ${ }^{14}$ (a reasonable assumption for major banks and a conservative one for regional banks based on past trends). We also assume that Tier I capital of domestic banks will grow in line with nominal GDP (i.e., mainly through bank profits, not new capital raising). ${ }^{15}$

$$
\text { Interest rate risk exposure }=\frac{\text { Domestic bond holdings } * \text { Duration }}{\text { Tier I capital }}
$$

\section{Results}

In the near term, both Abenomics scenarios show a substantial decline of the interest rate risk exposures of major and regional banks, mostly on account of BoJ purchases (Figure 7). Under the pre-Abenomics baseline, the interest rate risk exposures of major and regional banks would have risen over the medium term, highlighting growing financial stability risks. In contrast, under both complete and incomplete policy scenarios, they could decline substantially over the next two years, as the QQME is projected to reduce Japanese banks' JGB holdings despite higher government financing needs compared the pre-Abenomics baseline.

\section{Over the medium-term, however, whether financial stability risks remain lower depends critically on whether a complete policy package is implemented (Figure 7). If the policy} package is complete, banks' interest rate risk exposures may remain limited over the mediumterm on account of (i) slow growth in banks' JGB holdings due to fiscal consolidation and (ii) higher profitability and Tier I capital growth due to structural reforms. However, if the policy package is incomplete because structural reforms do not materialize or sluggish inflation expectations require further fiscal stimulus, bank's JGB holdings and interest rate risk exposure may rise quickly after the QQME, as banks may have to, once again, absorb large government financing needs and their profitability and Tier I capital growth may decline due to lower growth.

\footnotetext{
${ }^{13}$ Accounting losses may be lower, as mark-to-market losses could be partly offset by existing unrealized gains on domestic bond holdings. Rising interest rates may also improve the net interest margins on loans but these effects are not considered.

${ }^{14}$ In particular we assume the average remaining maturity of domestic bond holdings will decline from 2.5 to 2 years for major banks and from 4 to 3.5 years for regional banks over 2013-14.

${ }^{15}$ Alternatively, we can assume that Tier I capital will grow at a constant rate, say at 4.2 percent. This would take into account the fact that the average return on equity of Japanese banks is around 6 percent and the average dividend payout ratio of Tokyo Stock Exchange listed companies is around 30 percent. The results are broadly the same.
} 
Figure 7. Japanese Banks' Sensitivity to a 100-Basis-Point Interest Rate Shock

(Percent of Tier I capital)

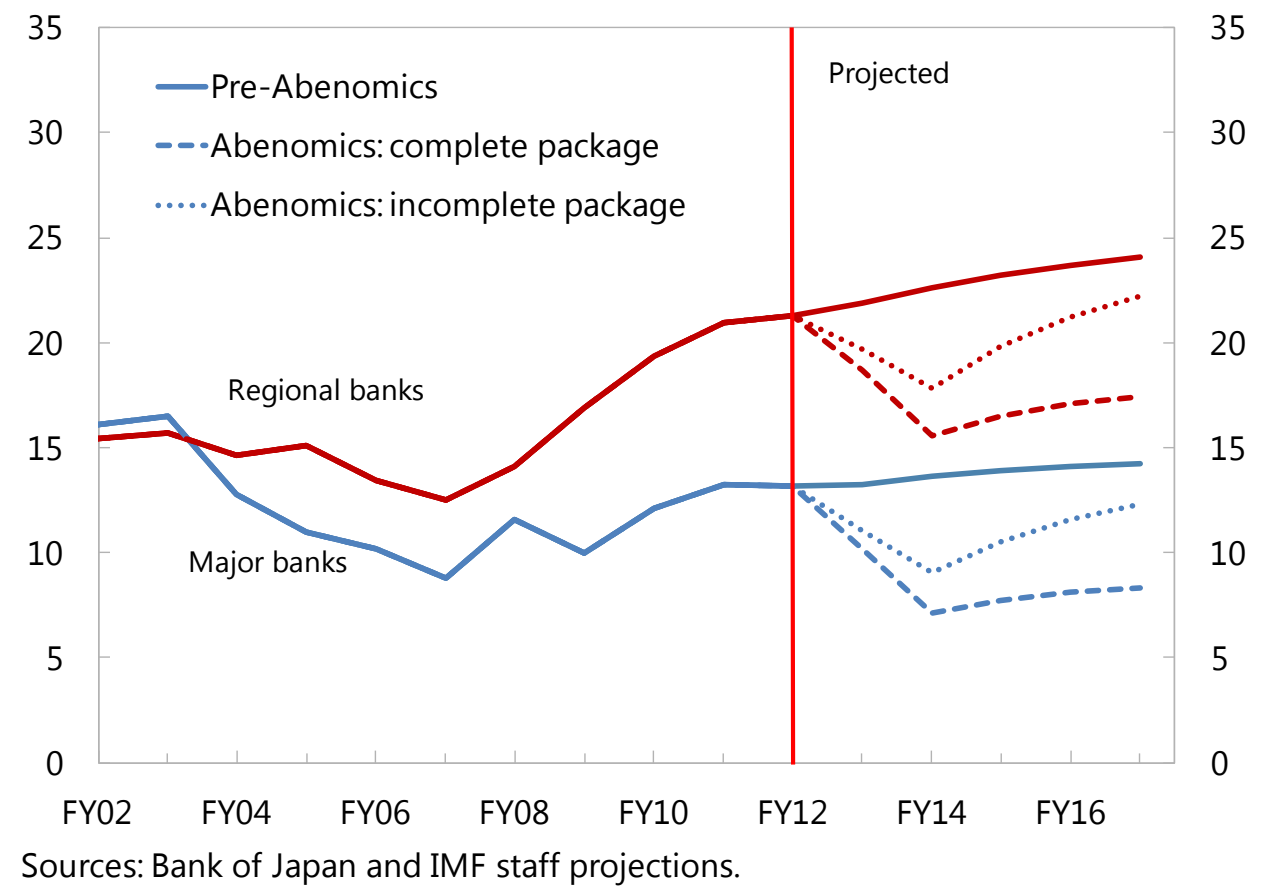

\section{Additional Risk Factors}

There are three caveats to this analysis. Although the scenarios illustrate that, if successful, Abenomics has the potential to reduce bank-sovereign linkages and banks' interest rate risk exposures (currently one of the key risks to the Japanese financial system), new risks to the financial system may emerge, which are not considered in this analysis.

- Major banks. The QQME could lead major banks to go overseas more aggressively as they reallocate their balance sheet. On the one hand, this would provide an opportunity as overseas loans account for only 10-15 percent of total loan portfolios for major banks, mainly in the areas of global and regional syndicated loans and project finance. On the other hand, this could raise foreign exchange (FX) funding risks. As discussed in Japan's Financial Sector Assessment Program (FSAP) Update, Japanese banks are well positioned to deal with exchange rate volatility as their net FX positions are small, limiting potential valuation losses. ${ }^{16}$ Furthermore, funding costs from some sources (especially FX swaps) were volatile during the euro area crisis, and in response, major banks have lengthened the maturity of FX swaps and issued more U.S. dollar denominated bonds. Nevertheless, they need to continue to actively manage their FX funding risks by using repos, interbank loans, certificates of deposit,

\footnotetext{
${ }^{16}$ See IMF Country Report No. 12/210 for a summary of the findings of the FSAP Update for Japan and IMF Country Report No. 13/253 (Annex V) for recent reforms and pending issues.
} 
and FX swaps (mostly in U.S. dollar). Sudden exchange rate movements may also create counterparty risk in FX swap markets, as most of these transactions are settled over the counter.

- Regional banks. A key risk factor for regional banks is low profitability stemming from weak loan demand in their core business areas. As a result, an important source of income for these banks is interest generated from long-term domestic bonds. In that context, if credit demand in the regional economies is slow to pickup, regional banks may decide to maintain their JGB holdings or, even, extend their maturity further, making them more susceptible to interest rate risk. This could happen especially if there is no credible growth plan and the policy package is incomplete. Though regional banks individually are small, as a group they are systemically important (with about 40 percent of banking system assets excluding Japan Post Bank and agricultural cooperatives).

- Rising risk premium. The scenarios focus on banks' sensitivity to a hypothetical interest rate shock. In other words, they do not attempt to capture the likelihood or severity of a shock under different scenarios. As discussed in Section III, the likelihood of a sharp rise in interest rates would likely be higher under incomplete policies.

\section{Conclusion And Policy Implications}

The paper examines how the policy package of Abenomics may affect the development of long-term sovereign yields and banks' exposures to interest rate risk. Empirical results suggest that the upward pressure on long-term JGB yields from deteriorating fiscal conditions has been offset so far by other factors, including a stable investor base with a preference for safe assets and increased purchases by the BoJ, but these effects are likely to decline over the medium term. Long-term interest rates could rise and the market's capacity to finance JGBs could further narrow unless fiscal and structural reforms are implemented to stimulate growth and reduce the public debt-to-GDP ratio. At the same time, the BoJ is set to take up large amounts of interest rate risk from Japanese banks to its own balance sheet in the near term, which could help banks provide more risk capital and support the government's growth objectives. In the medium term, however, the absence of sufficiently ambitious structural reforms and medium-term fiscal consolidation could push Japanese banks' JGB holdings and related interest rate risk exposure back to the baseline levels.

These findings have several policy implications. In particular:

- Monetary policy. Monetary policy alone cannot counter a potentially rising fiscal risk premium under current policies. Even if the BoJ expands its balance sheet to about 60 percent of GDP by 2014 under the QQME, our estimates indicate that long-term rates in Japan going forward are likely to be dominated by other factors, including deteriorating fiscal conditions. Accelerating the pace of inflation to reach the 2 percent target may help revive growth and 
contribute to a "normalization" of long-term rates, but without ambitious growth and fiscal reforms in train, the BoJ could face difficulties in maintaining stable long-term rates.

- Fiscal and structural reforms. More ambitious medium-term fiscal adjustments and/or structural reforms will be necessary to contain the risk of a surge in long-term rates, which is critical for fiscal debt dynamics. Our analysis shows that, since 2007, worsening fiscal conditions have contributed to an underlying interest rate increase of more than 1 percentage point. Based on the estimates, credible fiscal adjustments and structural reforms that lower medium-term projections of public debt and deficits can have an impact on the current level of long-term rates through a change in expectations. Successful implementation of Abenomics - including ambitious medium-term fiscal consolidation and growth reforms in addition to aggressive monetary easing - will be essential to keep long-term interest rates low and stable at levels broadly similar to nominal GDP growth rates.

- Financial stability. While the BoJ asset purchases could take up significant amount of interest rate risk from Japanese banks in the next two years, their JGB holdings and related interest rate risk exposures could rise again in the absence of accompanying fiscal and structural reforms. As recommended in the Japan's FSAP Update, strengthening capital requirements for domestically active banks and private sector-led consolidation in the regional banking sector could help mitigate downside risks of incomplete policies on the more vulnerable parts of the banking sector. By strengthening their capital base, such policies could also allow these banks to take better advantage of the potential reduction in their interest rate risk exposure and increase lending to small and medium enterprises (SMEs) and other corporations. That could, in turn, support the authorities' growth objectives. 


\section{REFERENCES}

Alper, E. and F. Lorenzo, 2011, "Public Debt in Advanced Economies and its Spillover Effects on Long-term Yields," IMF Working Paper No. 11/210 (Washington: International Monetary Fund).

Andritzky, J.R., 2012, "Government Bonds and Their Investors: What Are the Facts and Do They Matter?” IMF Working Paper No. 12/158 (Washington: International Monetary Fund).

Ardagna, S., F. Caselli, and T. Lane, 2004, "Fiscal Discipline and the Cost of Public Debt Service: Some Estimates from OECD Countries," NBER Working Paper Series No. 10788 (Cambridge, Massachusetts: National Bureau of Economic Research).

Arslanalp, S., and T. Poghosyan, 2013, "Foreign Investor Base and Long-term Sovereign Bond Yields in Advanced Countries," forthcoming in IMF Working Paper.

Arslanalp, S., and T. Tsuda, 2012, "Tracking Global Demand for Sovereign Debt for Advanced Economy Sovereign Debt,” IMF Working Paper No. 12/284 (Washington: International Monetary Fund).

Baba, N., 2012, "Sustainability of Debt Financing in Japan and the JGB Enigma," Global Economics Paper No. 215 (New York: Goldman Sachs).

Baldacci, E., S. Gupta, and A. Mati, 2009, "Is it (Still) Mostly Fiscal? Determinants of Sovereign Spreads in Emerging Markets," IMF Working Paper No.09/259 (Washington: International Monetary Fund).

Bank of Japan, 2012, Financial System Reports, October 2012. Available via the internet: https://www.boj.or.jp/en/research/brp/fsr/fsr121019.htm/.

Bank of Japan, 2013, Financial System Reports, April 2013. Available via the internet: http://www.boj.or.jp/en/research/brp/fsr/index.htm/

Brook, A., 2003, "Recent and Prospective Trends in Real Long-Term Interest Rates: Fiscal Policy and Other Drivers," OECD Economics Department Working Paper No. 367.

Engen, E. and R. Hubbard, 2004, "Federal Government Debts and Interest Rates," NBER Working Paper No. 10681 (Cambridge, Massachusetts: National Bureau of Economic Research).

Faini, R., 2006, "Fisal Policy and Interest Rates in Europe," Economic Policy, Vol.21, No.47, pp.443-89.

Hasegawa, T., and W.R. Lam, 2011, "Financial Asset Allocation of Japanese Households,” mimeo. 
Hauner, D. and M. Kumar, 2006, "Fiscal Policy and Interest Rates: How Sustainable is the 'New Economy'” IMF Working Paper No.06/112 (Washington: International Monetary Fund).

Hoshi, T., and T. Ito, 2012, "Defying Gravity: How Long Will Japanese Government Bond Prices Remain High?” NBER Working Paper No. 18287 (Cambridge, Massachusetts: National Bureau of Economic Research).

Ichiue, H., and Y. Shimizu, 2012, "Determinants of Long-term Yields: A Panel Data Analysis of Major Countries and Decomposition of Yields of Japan and the U.S.," Bank of Japan Working Paper, No. 12-E-7, May.

International Monetary Fund, 2013, "Japan: Article IV Consultation Report," IMF Country Report No.13/253. (www.imf.org/external/pubs/ft/scr/2013/cr13253.pdf)

Kinoshita, N., 2006, “Government Debt and Long-term Interest,” IMF working Paper No.06/63 (Washington: International Monetary Fund).

Lam, W. R., and K. Tokuoka, 2011, “Assessing Risks in the Japanese Government Bond Market,” IMF Working Paper No. 11/292 (Washington: International Monetary Fund).

Laubach, T., 2003, "New Evidence on the Interest Rate Effects of Budget Deficits and Debt," Federal Reserve Board Working Paper, April (Washington: Federal Reserve Board).

Poghosyan T., 2012, "Long-Run and Short-Run Determinants of Sovereign Bond Yields in Advanced Economies,” IMF Working Paper No. 12/271 (Washington: International Monetary Fund).

Tokuoka K., 2010, “Long-Term Outlook of JGB Financing,” IMF Working Paper No. 10/19 (Washington: International Monetary Fund). 